\title{
Winning the war of perception: american attempts to counter Germany's military influence in Turkey during World War II
}

\section{Ayşegül Avcı}

To cite this article: Ayșegül Avcı (2016) Winning the war of perception: american attempts to counter Germany's military influence in Turkey during World War II, Turkish Studies, 17:1, 202-219, DOI: $10.1080 / 14683849.2015 .1103189$

To link to this article: https://doi.org/10.1080/14683849.2015.1103189

曲 Published online: 13 Nov 2015.

Submit your article to this journal $₫$

Џ Article views: 256

Q View related articles $\square$

View Crossmark data ¿ 


\title{
Winning the war of perception: american attempts to counter Germany's military influence in Turkey during World War II
}

\author{
Ayşegül Avcı \\ Department of History, Bilkent University, Ankara, Turkey
}

\begin{abstract}
This article analyzes the emergence of the USA as a political power on the international platform against Germany in order to break the strong influence of the latter in Turkish military spheres. Turkey did not enter World War II, but it witnessed a war of perception, conducted by these two opposing powers to gain the trust of the Turkish statesmen. To accomplish that, in the early years of the war, the USA began sending experts to train Turkish military officers, and civilian and military students, and offered the opportunity to get educated at American institutions. During the war, the USA also tried to strengthen its influence by inviting journalists and military staff to observe technological advancements at factories, and victories in the fronts, and by showing movies presenting the power of the Allied armed forces.
\end{abstract}

ARTICLE HISTORY Received 3 March 2015; Revised 14 August 2015; Accepted 17 August 2015

KEYWORDS World War II; Turkish-American relations; war of perception; military relations; propaganda

Although Turkish-American relations were evolved into an alliance during the Cold War, American presence in Turkey's economic, cultural and military life during World War II brought these two countries closer. While the USA recognized Turkey's strategic and geopolitical importance, Turkey acknowledged the American potential as a counterforce in the European politics. The USA entered the political scene in Turkey first as a backup force to Britain against Germany during the war.

Turkish-American relations during World War II have been generally analyzed from the Cold War standpoint, and thus through Turkey's relations with the Soviet Union. ${ }^{1}$ However, since the early years of war, America emerged as a balancing force against Germany and only after 1943, did Turkey begin to consider America as a counterforce against British pressures and the Soviet threat. American war of perception successfully laid the 
foundation for what Örnek and Üngör called "the battle for establishing hegemony on the world of ideas," but the period deserves a separate analysis from the Cold War rhetoric as it has its own dynamics. During the 1930s, Turkey began to seek alliances and form better relations with other countries. By signing the Balkan Entente in 1934 and the Saadabad Pact in 1937, Turkey aimed to secure peace in the region. In addition, the Montreaux Convention in 1936 was to secure Turkey's sovereignty by regaining the control of the Straits. Increasing aggression from Italy was the main threat at the time for Turkey and after the assault on Albania in 1939, Turkey started engaging in an active dialogue with Britain.

Turkey's joint declaration with Britain on May 12, and with France on June 23, led to the drafting of a Mutual Assistance Pact on October 19, 1939. While situating the country on the side of the Allies, Turkish officials took measures to avoid direct entry to war with the second protocol. While Thomas and Frye noted that this protocol was an indication that Turkey would in no case take up arms against the Soviet Union, ${ }^{3}$ for Britain, the treaty guaranteed the effective collaboration of Turkey in the war effort. ${ }^{4}$ Several studies written on Turkish foreign policy during the war agree on Turkish authorities' particular attention to keeping the country out of the conflict. ${ }^{5}$ In order to accomplish that, Turkish statesmen knew the already established German influence had to be limited. This article focuses on the effort the USA has put forth to strengthen Turkey's neutrality, against Germany's influence in the Turkish military sphere. This study, however, does not focus on the hard-core military equipment aid, but instead on the ways in which the USA presented its military strength through responding to Turkey's requests by sending military technicians and experts; by opening its educational institutions to Turkish civilian and military students and interns; by inviting journalists and military officers for tours in the military facilities and fronts; and by screening American-made movies in Turkey that introduced the viewers' military advancements.

Germany's role in the modernization of the Ottoman army goes back to the period of Sultan Murad II when new military schools were opened. At these institutions, students were taught by European instructors and were sent to European countries for further training starting from $1827 .{ }^{6}$ With this initiative, Ottoman Empire aimed to adopt the military systems ${ }^{7}$ of the European countries in order to strengthen Ottoman forces. For 50 years, Ottoman military was restructured in compliance with the Great Powers but Prussia/ German system became dominant after the Russo-Turkish War of 1877$78^{8}$ because Sultan Abdülhamid judged that Germany was the only European great power which would not have an interest in the Ottoman territories and independence, and he admired German military power and efficiency. ${ }^{9}$ German influence in the Ottoman forces would peak during the 1912-13 Balkan Wars. The idea was to perform the reforms under the guidance of 
German military officers. ${ }^{10}$ On the other hand, the British system was dominant in the Ottoman navy. The Great Powers sent missions to establish their influence in Constantinople especially in the years preceding World War I. However, Germany's intense presence prevented the British naval missions political advantage "it merely provided a counterweight to German influence." ${ }^{11}$ This, too, ended when Turkey allied with Germany on September 2, 1914. When British and French missions left the country, German influence became unitary. As the war made German and Ottoman soldiers fellow fighters, despite the defeat, German influence was maintained amongst the Turkish officers who fought together with Germans during the first years of the Republic. ${ }^{12}$

As the two countries dressed their wounds, diplomatic relations were reestablished in 1924 and beginning from 1926, former military officers who were unemployed due to the restrictions brought on German armed forces by Versailles Treaty, were invited to teach at Turkish War Academies by signing personal contracts without the interference of the German government. These unemployed and/or retired military instructors evoked the admiration of Turkish students and officers, and their numbers increased especially after $1933 .^{13}$ To develop military relations Germany sent military missions to Turkey beginning from 1934 and received a warm welcome; published articles in Turkey about the World War I fellowship with Turks; carried on a propaganda through instructors; accepted Turkish military officers to learn modern German army and get training; invited Turkish journalists beginning from 1935 and opened the gates of its war industry. ${ }^{14}$ Germany also made investments in building and developing Turkish defense industry. ${ }^{15}$ As the amount of investments increased during the Nazi government, so did the number of German specialists. ${ }^{16}$ Their number was 2000 in the summer of 1939. ${ }^{17}$ There were also French and British instructors and specialists assigned to Turkey, and thus German efforts were directed to limiting this influence. ${ }^{18}$ While German influence increased in Turkish army, Britain replaced the French as the major foreign element in Turkish Air Force after the Turkish General Staff adopted the syllabus and instruction methods of Royal Air Force in 1938. ${ }^{19}$ Turkey welcomed military staff from different European countries because in the increasingly aggressive atmosphere of Europe, Turkey was careful not to slide into one particular camp. Turkish statesmen knew by experience that admiration toward and influence of foreign military staff could pull Turkey into hot conflict.

One of the first steps taken by the Turkish government was to balance the foreign influence. The US Ambassador to Turkey, John MacMurray, reported to the Secretary of State Cordell Hull in 1940 that "Turkish authorities are continuing to get rid of German technical experts hitherto employed," replacing the positions formerly held by Germans with specialists and advisors from Britain and France. He also included excerpts from the Turkish press, 
which reflected Turkish government's attitude in that period. As MacMurray stated, until the fall of France, Turkish newspapers had faith in the Allies. However, "upon French acceptance of the armistice conditions, the Turkish press gave vent to its disappointment in severe criticism of the French Government's action." ${ }^{20}$ German progress in the first years of war forced the Allies to sustain Turkey's faith in the Allied victory and to accomplish that goal, Britain had to maintain sending technicians and experts to Turkey, as had been the case since 1930s. In Başbakanlik Cumhuriyet Arşivleri, there are a few documents mentioning British experts and teachers and those are mainly in the aviation field during this period. ${ }^{21}$ However, especially after the fall of France, Britain had difficulty sending technical experts and specialists. In order to support the British, USA began sending military personnel in order to create the perception of a weakened Allied forces during the early 1940s.

Turkey welcomed the American military personnel. For instance, when "Alison" motors, produced in the USA began to be used in "Toma Hok" planes in 1942, specialist Lingeman stayed with the İzmir Aircraft Regiment for several months ${ }^{22}$ and upon his return, another specialist Graham was sent to manage the application of the motors. ${ }^{23}$ While American presence within the Turkish military spheres accentuated, Germany tried other ways to keep their technicians in Turkey to counterbalance the change. In New York Times, it was reported that Germany offered to deliver Turkey 12 modernized planes of the latest type (Messerschmitts and Junkers-88) in 1942 on condition that German technicians would accompany the planes. Turkey immediately rejected this offer although the country needed those planes and was trying to modernize armed forces. ${ }^{24}$

In addition to sending technicians and experts, America engaged in serious effort in the field of training to counter German presence in Turkish military. Turkish officials who aimed to limit German influence and build balance welcomed this effort. Turkish Government requested the assignment of an American instructor to the Turkish Air Force, which involved teaching both at the War School and Navy School; American response was affirmative to this request. $^{25}$

When Turkey invited another American officer to give aviation courses in Turkish academies, a consultant for the US State Department, Wallace Murray, urged for the approval of this request for ideological reasons. He wrote:

The United States is regarded in Turkey and elsewhere in the Near East as not only being pre-eminent for technical and aviation efficiency but also for having no imperialistic aims in that area. The modern Turkish Government is reluctant to invite any foreign military instructors, but faced with the necessity of doing so, prefers to turn to us. Our own position in Turkey and the Near East would be strengthened, and the policies of this Government furthered, by compliance with the Turkish request. ${ }^{26}$ 
Turkey succeeded in attracting the attention of the USA, which started to perceive Turkey as one of the key countries in the Middle East. For Turkish statesmen, compared to the other belligerents, America was a more secure power bereft of any imperialistic ambitions that could put Turkey in a difficult position before or after the war. Despite the difficulty of sending trained officers to a "neutral" country, the USA used it as a means of propaganda, to increase its prestige and to secure the positive attitude of the Near Eastern countries. Lieutenant Colonel Demas T. Craw was assigned to this duty. American influence in the Turkish military training continued after that date and many instructors came to Turkey to teach military officers and students, especially in the aviation field. In 1943 Lieutenant Guy Lovine, Second Lieutenant Atlee Van Fleet, Sergeant Frank Booth and Sergeant Donald Way came to Eskişehir First Air Division. ${ }^{27}$

Before the war, in addition to welcoming experts into the country, Turkish government also supported officers, employers, cadets and students to get education and training or do internships in German military factories and armed forces. ${ }^{28}$ As the tension increased in Europe, Turkey tried to limit the number of Turks going to Germany. Eighty percent of the Turkish students and cadets who were studying abroad were in Germany in the spring of 1937, but in 1939, Turkish leaders were encouraging them to go to England or France. ${ }^{29}$ The aim was again to limit the German influence by decreasing the number of students and cadets in Germany, because training and educating Turkish military and civilian students by sending them abroad was another way in which their ideas and lifestyles were shaped. Depending on the reports of the General Directorate of Security Affairs, which investigated the people and institutions conducting Nazi propaganda in Turkey during World War II, Doğaner put forward that

the students and military officers who receive education in Germany take an exam on Nazi methods and ideology. A part of these students are members of the Nazi organization and bring back the Nazi influence after they complete their education. ${ }^{30}$

Turkish Ambassador to Germany, Hüsrev Gerede's report reveals the extent of Nazi influence in 1940 as "some [of the Turkish students and cadets] pin Nazi badges in their collars, and some salute like Nazis." ${ }^{31}$ Gerede also wrote in his memoir, one of his first assignments in Germany was to organize the return of Turks in order to end this kind of German influence. ${ }^{32}$

In 1940, Turkey began retrieving military students from Germany. By September, they all returned to Turkey ${ }^{33}$ and were directed to Britain and the USA. $^{34}$ While some of the Turkish pilots were trained in Britain and British military bases in the Middle East, ${ }^{35}$ the USA also emerged as a new option for Turkish military and civilian students to get training in the military field. After taking English courses at the American College of Istanbul, 50 
army officer and students, who had been called back from Germany, were redirected to the USA. ${ }^{36}$

In a report prepared for the Office of Strategic Services (OSS) Coordinator of Information Colonel William Donovan, it was written: "Today foreign exchange problems have greatly reduced the number on private account. The Government has recalled home its bursaries from Continental Europe but not from America." ${ }^{37}$ In Başbakanlık Cumhuriyet Arşivleri, there are many documents listing the names of the students and cadets who would be sent to the military institutions in the USA. ${ }^{38}$ Generally, their expenses were paid in foreign currency, which was rather appealing for Turkey as the foreign currency reserve was limited. However, a part of the expenses were paid through Lend-Lease. ${ }^{39}$

On the other hand, although very few in number, there were also students and cadets who were sent to Germany in the following years of the war. Before the war, Turkey bought armaments from Germany based on the clearing system, which was profitable for both countries. Commerce between the two continued and Turkey bought German-made armaments during the war due to economic difficulties and Turkey's balance politics. Required to learn about the equipment, Turkey sent military and civilian students and staff to Germany in a limited number. ${ }^{40}$ In 1944, after cutting diplomatic relations with Germany, Turkey organized the return of Turkish bursaries. Among 292 students in Germany, there was only one, getting education in a military factory. The rest were all civilian students. ${ }^{41}$

In the National Archives and Records Administration, there are documents reporting Turkey's demands for relevant visas for the acceptance of Turkish military and civilian students to American schools, factories, workshops and other military institutions. ${ }^{42}$ Considering the risks of going to America by sea, the authorization for relevant visas took time. However, a note from Chief of Division of Near Eastern Affairs Paul H. Alling revealed the efforts of speeding up this process. Emphasizing the "particularly important relations with Turkey at the present moment, it is recommended that the War Department be urged to give as favourable consideration to the Turkish Government's request as may be compatible with our defence requirements." ${ }^{43}$ American officials supported the idea of Turkish students, cadets and military officers getting education, training and doing internships in American institutions and schools, because of the strategic importance of Turkey. The role of the USA in training the Turkish military personnel both in Turkey and America should be taken in the propaganda point of view because although it did not officially enter the war until the attack on Pearl Harbor on December 7, 1941, from the very beginning it took part in conducting a war of perception against Germany to reinforce Turkish attitude toward the Allies and to prevent Turkey to slide toward Germany. After analyzing the risks of admitting foreign civilian and military students as well as 
military staff to American factories and institutions, the War Department gave authorization, considering the benefits for American policy. ${ }^{44}$

America also considered inviting high-ranking military officials including President İsmet İnönü for a tour to war industry plants. The aim was to show the vast resources of American military power, and thus to gain the trust of Turkey for the eventual victory. ${ }^{45}$ Although it was thought that Inönü could not leave his country for that trip, as stated in a State Department memo, being a military figure, he would "desire to see our armament progress, or at least to be invited to do so." Due to the strategic position of Turkey, acting as a buffer state preventing the advancement of the Axis forces into the Middle East, the USA aimed to prevent German influence because, as stated in the same document "There is probably no neutral country more important to us at that moment than Turkey." 46 As wartime needs created new technologies and impelled US industry on an "extraordinary surge of growth," 47 the USA aimed to impress the Turkish statesmen and military officers with its capacity, the might of the Allied industrial advancements and their superiority over Germany.

Turkish diplomats had always admired military success, and Germany's success in the war was fascinating until 1943, but it also destroyed the balance in the Mediterranean. ${ }^{48}$ By May 1941, Aegean Islands, Crete, Greece and Yugoslavia were invaded by Germany, and Bulgaria joined the Axis. Successful progress of the Axis forces, the fall of France and England's inability to help Greece failed Turkish trust for an Allied victory and were signs for Turkey not to trust England's guarantees. Although Vanderlippe argued "İnönü always believed that Germany would lose the war and was personally committed to the Allied Cause from the beginning," 49 a conversation with MP Kazım Karabekir on May 12, 1941, revealed his doubts about British strength against German forces. ${ }^{50}$ Despite German success in the war, Turkey was anxious about the German victories and critical toward its progress in the Balkans and Europe. Journalist Necip Ali Küçüka wrote Germans wanted to dominate the Balkans and Europe to accomplish its financial policies, instead of liberating the region from British domination as they claimed. ${ }^{51}$ Aware of Turkey's attitude toward the war, the USA put great effort to show the power of the Allied technological progress in the military field.

There is a fund in the USA "for entertaining military and civil officials of certain foreign countries whose good-will is desired." 52 Being among the "certain" countries, Turkey's "good-will," toward the belligerents was important, and in order to maintain that, the War Department invited high-ranking military officers. However, troubles of transportation and supplying necessary safety measures made this five-week trip impossible. One of the considerations of the War Department was to show "courtesy" to Turkish officers, and thought Turkey would be "appreciative," too. Since European powers were also interested in presenting their war industry, the War Department's 
invitation would balance the Axis attempts. When Turkish Ambassador to the US Mehmet Münir Ertegün declined it "with genuine reluctance," War Department decided to invite 41 Turkish Army and Naval officers who were already in America, pursuing graduate study and obtaining practical experience in factories, to give them a tour of a week or ten days to show them the developments in the war industry. ${ }^{53}$

Counselor of Turkish Embassy Orhan H. Erol reported that Turkish officials who visited American military installations were "tremendously impressed" by the American development in the past several months. Moreover, Erol said that their belief in American victory became stronger after they read the report. ${ }^{54}$ The usage of similar expressions for Germany by the Turks who visited German installations shows the function of the USA as a counterforce in this war of perception. After 1941 Allied forces began to push Axis forces out of North Africa and created a change in Turkey's attitude toward the Allies. This evolution was described in New York Times as from "very neutral" to "a non-fighting ally of Britain." ${ }^{55}$ Conducting a successful war of perception in convincing the Turkish military officials and statesmen of the ability and means of the Allies to win this war, the USA was able to counterforce Germany's propaganda using the same method.

Germany was still an important force and tried to maintain its influence in Turkey. On the occasion of twenty-third anniversary of the Turkish National Assembly, Democratic Senator from Florida Claude Pepper gave a speech on April 23, 1942. After celebrating and praising Kemalist reforms, he emphasized the intensity of German propaganda in Turkey. However, he added that the Turks did not to let the Germans use Turkey's strategic position. ${ }^{56}$ The speech revealed the interest in Turkey's position at the war and in order to maintain non-belligerent state of Turkey, the USA needed to continue this war of perception.

One of the main concerns of the Turkish statesmen at the time was Soviet intentions over Turkey, and the alliance between the latter and Germany was an important factor in pursuing a policy of distancing. German attack on the Soviet Union on June 22, 1941, relieved the Turkish anxiety. German Foreign Minister Joachim Ribbentrop told Gerede that Germany attacked Russia because the latter wanted to take Turkey and the Balkans under its own sphere of influence; but Germans could not let Turkey to become dependent on a foreign country and they were fighting for peace and integrity in the whole world. ${ }^{57}$ Deputy Faik Ahmet Barutçu wrote that this war caused great joy in Turkey, both among public and politicians. ${ }^{58}$ Four days before the German attack on the Soviet Union, Turkish-German Treaty of Friendship was signed but despite this agreement and the "joy," Turkey did not intend to join the war. İnönü said that this Treaty affected the TurkishGerman relations in the most favorable way but added that commitments of his government toward Britain would continue. ${ }^{59}$ 
Ideologically Turkey supported the cause of the Allies. Ambassador of the UK to Turkey, Sir Hugh Knatchbull-Hugessen, described Turkey's position to the British Ambassador to the USA, Viscount Halifax, as

sitting on the fence, but at least they are sitting with their faces in our direction and their backs to Germany, though continually squinting over their shoulders to see what danger is brewing behind them-and always squinting sideways at Russia. $^{60}$

When Germany declared war on the USSR, the attitude of Turkey softened toward Germany, which used Turkey's fear from Russia as propaganda. There had already been a pro-German sentiment in Turkish armed forces, especially among the pan-Turanists. ${ }^{61}$ Germany fed into this ideology and the already existing pro-German sentiment by inviting important names to Berlin. General Erkilet visited the German troops in the eastern front in 1942. The aim was to show the superiority of German army over the Soviets and that they would win this war. Narrating this visit in his memoirs in a pro-German and anti-Soviet tone, Erkilet wrote how friendly the German generals were and how they focused on the World War I alliance between the two countries. He even interpreted German war aims in a superior meaning while criticizing Russia for being weak and brutal. Erkilet believed in the German victory at the end of the war. ${ }^{62}$ The German strategy in this war of perception was to turn Turkey's focus toward the Soviet Russia instead of the Allies, and secure Turkey's support, or at least neutrality.

Despite German efforts to exaggerate Soviet threat, the cautious policy of the Turkish statesmen proved right, since by the end of November 1942, German forces in Stalingrad began facing difficulties under the harsh winter conditions. After a long and devastating war, on February 2, 1943, German forces surrendered to the Soviet Union. This battle was the turning point in the progress of war; Turkey began to favor the Allied victory in a more secured vision. However, victories in the Battle of Stalingrad and North Africa did not guarantee Turkey's entry to the war. Germany could still bomb important cities in Turkey and even invade the country.

Efforts to portray a powerful Allied unity continued through the invitation of Turkish military staff to Allied fronts. On the occasion of the twenty-fourth anniversary of foundation of the Turkish National Assembly, Republican Senator from Pennsylvania, James J. Davis, gave a speech on the Senate praising Turkish democratic way of life and emphasizing Turkey's strategic position at war. He also mentioned Turkish military observers' visit to the Allied fronts in Africa. A Turkish mission under General Salih Omurtak with 12 prominent military and political figures met General Dwight Eisenhower and other American and British officers in Tunisia. After the tour General Omurtak expressed his conviction of the Allied victory, saying that Allies were much stronger than the Axis powers. Senator Davis quoted 
from Omurturak that he was extremely well pleased with his tour and very much impressed with the Allied war effort. ${ }^{63}$

Sending military staff to Turkey, inviting Turkish military officials, opening military factories, institutions and schools to Turkish students, cadets and officers were all important in this war of perception, however, their influence was limited because they did not reach the general public. An effective way to impress the public was inviting journalists. In July and August 1942, a group of Turkish journalists went to Berlin, Viennese and Eastern front under the head of Press Manager of Turkish Government Selim Sarper. ${ }^{64}$ In accordance with Turkish balance policy, a similar group went to England and America upon invitation. That visit covered a tour of army, navy and aircraft production centers, and the journalists attended press conferences of the President Roosevelt and the Secretary of State. Five journalists who were invited to America were Hüseyin Cahid Yalçın, editor of Yeni Sabah, and a deputy; Ahmet Emin Yalman, editor of Vatan, and a professor at University of İstanbul; Ahmet Şükrü Esmer, foreign news editor of Ulus, and President of the Foreign Affairs Commission of the Turkish National Assembly; Abidin Daver, editor of İkdam, and a deputy; and finally Zekeriya Sertel, editor of Tan. Yalman, Esmer and Sertel were all graduates of Columbia University. ${ }^{65}$

Yalçın wrote about his visit to America and their meeting with Roosevelt in Yeni Sabah with a favorable tone. Yalçın stated that Roosevelt emphasized Turkish friendship while despising Axis aggression around the world. He also underlined that American aid to democracies like Turkey would help to beat the Axis powers. ${ }^{66}$ Yalman indicated his impression by the pace of American industrialism, devotion of American people to increase the production and their determination of winning the war. ${ }^{67} \mathrm{He}$ also wrote about how, after his return, he found that Vatan had been suspended for 90 days. The reason was a joke made by Charlie Chaplin who "had spoken via short wave on the Turkish Hour from New York, and had told a Nasreddin Hoca story about men and donkeys, giving it a twist that portrayed Hitler and Mussolini as asses." The picture of Chaplin caricaturing Hitler was published in Vatan. Upon German Ambassador to Turkey Franz von Papen's protest, Vatan was suspended. Yalman went to Ankara to protest against the extent of the severe punishment. The answer of Turkish officials was

Don't you know that Hitler is mad? Is it right to provoke a madman when he has large armed forces close to our frontier and is asking himself whether he made a mistake in not attacking Turkey before the offensive he has just started in Russia? You deserve ninety days punishment for your thoughtlessness. ${ }^{68}$

Yalman's anecdote and Yalçın's article show the contradiction. Although Turks were impressed by American technological and industrial development, 
they felt the need to remain neutral as a result of the anxiety felt for the Germans.

During this period, newspapers reached the majority of the public but movies were more attractive. They were used by the belligerents to exhibit their military power and to expand their influence. The use of movies as propaganda was widespread in the countries that were engaged in active war as well as in neutrals like Turkey. Germans in Turkey, like von Papen, organized meetings and invited Turkish high-officials. During these meetings, they showed movies presenting German high technology, invincible military power and their victories. According to the "Current Developments in Turkey" report of 1940, there was concern over the hegemony of Germanmade movies in Turkey. German war films were shown at public theaters besides Turkish Military Academy and at the General Staff School in Istanbul. $^{69}$

After 1942, on the other hand, the number of American movies aired surpassed that of the German movies. In a telegram from Lacy W. Kastner, Promotion and Publication Specialist to John M. Begg, Assistant Chief of Division of Cultural Relations, the importance of showing as much American movies as they could in Turkey was emphasized. He asked for the diplomatic assistance necessary for the transfer of those movies to Turkey. ${ }^{70}$ An excerpt from American Ambassador to Turkey Laurence A. Steinhardt's letter on November 13 put forward the importance of the matter:

\begin{abstract}
Not only have the Germans made every effort to provide films for the Turkish market most of which have a propaganda twist but they have been actively endeavoring to acquire theaters for the presentation of their films. You and the American Motion Picture Industry are in a position to render a definite service to our country and to make a not inconsiderable contribution to our war effort if you will exert your utmost efforts to assure the exhibition of your best pictures in Turkey. I appeal to you, therefore, to keep up a steady flow of current picture during the war. ${ }^{71}$
\end{abstract}

The report prepared by American Vice Consul Ellis A. Johnson in 1943 about the American Motion Pictures in Izmir, gave the percentage of American movies presented in the city as 87 while German movies covered only 7 percent. It was also stated that American movies were the most popular ones, as the public did not prefer to watch movies of Nazi origin. The American-made motion pictures had an important influence on local political attitude in favor of the Allied cause. ${ }^{72}$ By showing movies, Americans were also spreading American lifestyle, culture and ideology. American movies served for not only winning the Turks on their sides, but also spreading westernization.

By the end of 1943, the Allied forces pushed back the Axis to a large extent but theaters in Turkey continued showing American movies, the USA kept sending instructors, technicians and officers to Turkish schools and military 
facilities, and kept its doors open to Turkish students, cadets and military officers. The war of perception that introduced American way of life, ideals and system, and the military success of American forces "greatly enhanced" Turkey's perception of America. ${ }^{73}$ Since the first years of the war, according to American liaison officer Ray Graham, Turkey had regarded "all foreign powers with the possible exception of the U.S.A., as fundamentally hostile to Turkish national interests." ${ }^{.74}$ His opinion can be supported by the Turkish attitude toward the Allies from 1942 onwards when Britain increased its pressure on Turkey to enter the war. Although the USA agreed to recognize Britain's responsibility in the Middle East at the Casablanca Conference, Roosevelt rejected Churchill's insistence on Turkey's entry to the war in the following meetings throughout 1943. Both Roosevelt and Churchill sent a plane to take İnönü to Cairo, and İnönü took Roosevelt's plane. Although Cordell Hull described this situation as a "friendly rivalry between Mr. Roosevelt and Prime Minister Churchill,"75 the transportation crisis before the Cairo Conference was a symbolic climax showing the difference in the policies of the USA and Britain, while at the same time showing Turkey's preference of American over British policy. The only time the USA opposed to Turkey's neutrality was at a speech given by Cordell Hull on April 9, 1944. America's positive approach drew a US portrait in the minds of Turkish leaders who were suspicious about the post-war plans of Britain and the Soviet Union threatening Turkey's integrity, as a counterforce against Britain and the USSR. $^{76}$

Turkey's perception of America's role in the post-war European politics was strengthened throughout the war. The educational development of Turkish students both in Turkey and in the USA was considered as "a means of strengthening through education American-Turkish relations" in 1944. The same year, State Department appointed a Cultural Attaché to Ankara in order to build cultural and intellectual relations as the first step to consolidate its presence in the Middle East to compete with already established European influence. ${ }^{78}$ The USA established an extensive intelligence web in Turkey during the war beginning with the appointment of Donovan as the Coordinator of Information on July 11, 1941. Being a neutral country "Turkey was a hive of espionage and a haven for antiNazi Germans." "They could gather information about the activities of Axis countries as well as the conditions of the invaded countries. Moreover, OSS agents were able to establish a close contact with the principal offices of Turkish Security Organization in Ankara, İstanbul and İzmir. ${ }^{80}$ Realizing the geopolitical importance of Turkey during the war through military and intelligence operations, ${ }^{81}$ American investments on Turkey were maintained, and then were increased with the Truman Doctrine that marks the beginning of the transformation process of the Turkish armed forces from Prussian/German model to American model. ${ }^{82}$ 
Considering the developments that paved the way for an AmericanTurkish alliance in the Cold War, the experiences of World War II enabled both countries to learn, understand and benefit from each other in the following periods.

\section{Disclosure statement}

No potential conflict of interest was reported by the author.

\section{Notes}

1. Ülman, in Türk-Amerikan Diplomatik Münasebetleri, writes that the relations between the two countries were not close until the end of World War II and were formed generally through Britain. Although Turkey found American policy more favorable when compared to British after 1942, it was Turkey's search for American aid to strengthen its position against the Soviet Union in 1945, which enabled an alliance between the two countries. Similarly Toker in Türkiye Üzerinde 1945 Kabusu writes that before 1946 the importance of Turkey for America lay only in the regulation of the Turkish Straits and it played an important role in Turkish foreign policy only in 1946, by sending the USS Missouri. Gramer in "Turkey in Search of a Protector" argues that Turkey's foreign policy depended on the "traditional search for a protector" against the Soviet Union. This was the main motive in Turkish-American relations during and after World War II. In his short article of eight pages, which covers the years of 1918-47, Gramer analyzes the Turkish foreign policy without understanding the intention of the Republic to stay as a neutral buffer state, ignoring Italian and German aggression. Weisband in Turkish Foreign Policy also argues that one of the main determinants of the Turkish foreign policy was the Soviet Union, which could have a free hand in Eastern Europe and threaten the sovereignty of Turkey. Thus, it "dragged her foot" to preserve its power in case of a Soviet aggression. By starting the book from 1943, when Turkey felt the pressure of the Allies more intensely, Weisband analyzes the period through the Cold War glasses but ignores the importance of Germany as another influential motive in the formation of Turkish foreign policy.

2. Örnek and Üngör, Turkey in the Cold War, 2.

3. Thomas and Frye, United States and Turkey, 91.

4. Deringil, Turkish Foreign Policy, 82-3.

5. Millman in "Turkish Foreign and Strategic Policy" argues that Turkey sought for an alliance with Britain against Italy's aggression and Germany's economic dominance as it was the only power that could shelter Turkey "from attack, defeat or disaster" even if Turkey had to enter the war. Turkey intended to fulfill the requirements of the alliance before the fall of France, thus it could not be defined as a neutral state at the beginning of the war unlike the revisionists claim but Turkey's policy evolved into non-belligerency after 1940. Vanderlippe in "A Cautious Balance" writes that Turkey desired balance in Europe; it did not equal neutrality but Turkish interests would be served best by staying out of the war. Weber on the other hand argues in The Evasive Neutral that the best interests of Turkey were served by opportunism. During the war, Turkey bargained with both sides for economic and military aid, thus Weber defines Turkey's 
wartime position as "evasive neutral" meaning a non-belligerent but by no means a cog in the wheel. It is "a brilliant accomplishment by all standards except those of honesty and integrity" since it did not live up to the sanctions of 1939 alliance with Britain and France. Putting aside morality, Deringil in Turkish Foreign Policy claims that Turkey's economic and military incapability forced it to be an "active neutral," and the decision to stay out of the war was taken considering national benefits. Being surrounded by the belligerents, Turkey was careful not to let the war in from its doorsteps. Throughout the war, Turkish chrome ore was the major element of the commercial agreements with both sides, and the lendlease aid was counterbalanced by Germany. Fox in Power of Small States argues that the power of small states came from their ability to convince the great powers that their neutrality was advantageous to the great powers, and both the Axis and the Allies sought to prevent them from shifting to the other side; in return the great powers could avoid fully mobilizing the armed forces of the small states. As Fox claimed, Turkey was successful to stay out of the war by establishing a balance through commercial and diplomatic agreements.

6. Akmeșe, Birth of Modern Turkey, 4-5.

7. The word "system" is used here to describe the military traditions in general, including the regulation of military units, discipline, strategy, etc., that the Ottoman Empire aimed to adopt during the modernization period. One important aspect of the modernization was training the military students.

8. Güvenç, "ABD Askeri Yardımı," 255 and Özcan, "Cumhuriyet Ordusunda Prusya," 179.

9. Akmeșe, Birth of Modern Turkey, 20.

10. Türk Silahlı Kuvvetleri Tarihi, 192.

11. Rooney, "British Naval Missions," 25.

12. Özcan, "Cumhuriyet Ordusunda Prusya," 196.

13. Özgüldür, Türk-Alman İlişkileri, 64-5.

14. Ibid., 91-7.

15. Koçak, Türk-Alman İlişkileri, 51-5.

16. Ibid., 176, 184-200.

17. Glasneck, Türkiye'de Faşist Alman Propagandası, 75.

18. Özgüldür, Türk-Alman İlişkileri, 77-9.

19. Leiser, "Turkish Air Force," 383.

20. NARA, "Developments During the Past Seven Months in the Attitude and Policies of Turkey Relative to the International Situation," October 26, 1940, No. 1583, roll 23, M 1224, RG 59.

21. BCA, "İngiliz uyruklu 10 kişinin İngiltere'den satın alınan uçakların montaj işleri ile, bunların özelliklerinin kendi pilotlarımıza öğretilmesi için hava birliklerinde görevlendirilmelerine izin verilmesi," November 24, 1939, 30..18.1.2/ 89.111..13; "İngiliz Uyruklu A.W. Newson'un Çankırı piyade atış okulunda havacı subaylara ingilizce ders vermek üzere çalıştırılmasına izin verilmesi," November 27, 1943, 30..18.1.2/104.2..31; “Trakya ve Batı Anadolu'da yaptırılan askeri inşaat mahalline gönderilmek üzere 2 İngilizin Trakya ve Çanakkale 2. yasak bölgelerine girmelerine izin verilmesi," December 17, 1940, 30..18.1.2/ 93.115..3; and "Çanakkale top mevzii-inşasında çalışmasına izin verilen İngiliz müh. J. W. Perkins'in eşinin de Çanakkale'de oturmasına izin verilmesi," June 22, 1940, 30..18.1.2/91.59..10.

22. BCA, "Amerikalı alison motor uzmanı Lingeman'ın 2. tayyare tugayı emrinde çalıştırılmasına izin verilmesi," July 8, 1942, 30..18.1.2/99.59..3. 
23. BCA, "Amerikan uyruklu uzman Graham'ın İzmir havacılık alayındaki alison motorları üzerinde çalıştırılması," September 14, 1942, 30..18.1.2/99.82..20.

24. Taylor, "Nazi Plane Offer Made to Turks."

25. NARA, “American Instructor for Turkish Air Force," November 13, 1941, No. 867.248.117, roll 29, M 1224, RG 59.

26. NARA, "Wallace Murray to the Department of State," October 13, 1941, No. 867.20/123, roll 25, M 1224, RG 59.

27. BCA, "Amerikan uyruklu 4 subay ve astsubayın liberatör bölüğünün yetiştirilmesi için Eskişehir 1. hava tümeni emrinde çalıştırılmasına izin verilmesi," December 22, 1943, 30..18.1.2/104.4..18.

28. Koçak, Türk-Alman İlişkileri, 38-45, 174-84.

29. Ibid., 181.

30. Doğaner, “Türkiye'de Nazi Propagandası," 69.

31. BCA, "Almanyadaki talebemizin hali ve bundan sonra talebe göndermek şekli hakkında," September 1940, 30..10.0.0/142.14..8.

32. Gerede, Hüsrev Gerede'nin Anıları, 40.

33. See note 31 above.

34. BCA, "Amerikaya gönderilecek talebeler hakkında," November 9, 1939, 30..10.0.0/142.13..21.

35. Leiser, "Turkish Air Force," 389.

36. BCA, "Kararname," September 13, 1940, 30..18.1.2/92.90..1.

37. NARA, “C. D. Dillon to Colonel Donovan," November 14, 1941, roll 118, M 1642, RG 226.

38. Some of these documents related to the military education are: BCA, "Ingiltere ve Amerikaya gönderilecek tayyare mühendisleri hakkında," September 15, 1943, 30..10.0.0/61.410..20.; "Milli müdafaa vekaletince tahsil maksadile Amerika, İsviçre ve Almanyaya gönderilecek 31 talebenin tahsil masrafları hakkında," November 3, 1942, 30..10.0.0/133.957..1.; "Tahsil maksadile Amerikaya gönderilecek tabip yüzbaşı Safaya verilecek 3000 liralık döviz hakkında," June 12, 1943, 30..10.0.0/133.958..5.; "İngiltere ve Amerikaya gönderilecek havacılar için talep olunan 75.000 liralık döviz müsaadesine dair," June 23, 1941, 30..10.0.0/ 200.364..14.; "Kararname," June 18, 1943, 30..18.1.2/102.44..13; and "Kararname," July 18, 1944, 30..18.1.2/106.51..13.

39. BCA, "Letter from J. Raleigh Nelson to Mr. Straub," March 29, 1941, 30..10.0.0/ 57.386..12.

40. BCA, "Kararname," May 12, 1943, 30..18.1.2/101.34..2; and "Kararname," September 8, 1943, 30..18.1.2/102.64..2.

41. BCA, "Almanyada bulunan öğrencilere yardım edilmesi hakkında," September 18, 1944, 30..10.0.0/206.405..7.

42. NARA, "J.V.A. MacMurray to the Secretary of State," September 16, 1940, No. 811.22767/40, Box No. 3746, Decimal File 1940-1944, RG 59.

43. NARA, "Note from Paul Alling," September 23, 1941, No. 811.22767/49, Box No. 3746, Decimal File 1940-1944, RG 59.

44. NARA, "Secretary of State to Turkish Ambassador at Ankara," November 17, 1941, No. 811.22767/56, Box No. 3746, Decimal File 1940-1944, RG 59.

45. NARA, "Memorandum for the Chief Division of Near Eastern Affairs, Department of State," No. 811.22767/63, Box No. 3746, Decimal File 1940-1944, RG 59.

46. Ibid.

47. Chandler, "U.S. Industrial Enterprises," 5.

48. Deringil, Turkish Foreign Policy, 106-13. 
49. Vanderlippe, “A Cautious Balance," 64.

50. Karabekir, Ankara'da Savaş Rüzgarları, 288.

51. Necip Ali Küçüka, "Balkanlar ve Almanya," Cumhuriyet, 09.02.1941.

52. NARA, "Memorandum," January 22, 1942, No. 811.22767/64, Box No. 3746, Decimal File 1940-1944, RG 59.

53. NARA, "Paul Alling to Mr. Welles," March 31, 1942, No. 811.22767/68, Box No. 3746, Decimal File 1940-1944, RG 59.

54. NARA, "Memorandum about Counselor of Turkish Embassy's Report of Visit of Turkish Officials to American Military Installations," April 29, 1942, No. 811.22767/69, Box No. 3746, Decimal File 1940-1944, RG 59.

55. Callender, "Turks, Spain and Italy Begin to See the Light."

56. Pepper, "88th Congressional Records," April 23, 1942, Congressional RecordSenate, 3670.

57. Gerede, Hüsrev Gerede'nin Anıları, 209.

58. Barutçu, Siyasi Hattralar, 494-5.

59. İsmet İnönü'nün TBMM'deki Konuşmaları, 20-1.

60. NARA, "Extract from Letter Dated June $5^{\text {th }}$ from the British Ambassador at Ankara to Lord Halifax," June 30, 1942, roll 23, M 1224, RG 59.

61. Some of them were Generals Emir Erkilet, Ali Fuat, Asım Gündüz and Fevzi Çakmak in Vere-Hodge, Turkish Foreign Policy, 149.

62. Erkilet, Şark Cephesinde Gödüklerim.

63. Davis, "89th Congressional Records," April 22, 1943, Congressional RecordSenate, 3694.

64. Glasneck, Türkiye'de Faşist Alman Propagandası, 23.

65. NARA, "Memorandum," September 18, 1942, No. 811.91267/60, Box No. 4062, Decimal File 1940-1944, RG 59.

66. Yalçın, "Roosevelt ve Turkiye."

67. Yalman, Yakın Tarihte Gördüklerim, 322-7.

68. Yalman, Turkey in My Time, 193-4.

69. NARA, "Current Developments in Turkey During the Month of July, 1940," August 19, 1940, No. 867.00/3098, roll 23, M 1224, RG 59.

70. NARA, "Lacy W. Kastner to Mr. John Begg," July 22, 1942, roll 29, M 1224, RG 59.

71. NARA, "Laurence A. Steinhardt to Secretary of State," December 15, 1942, No. 867.406 MOTION PICTURES/30, roll 29, M 1224, RG 59.

72. NARA, "Motion Pictures-Izmir, Turkey," May 3, 1943, No. 867.406I MOTION PICTURES/56, roll 29, M 1224, RG 59.

73. Harris, Troubled Alliance, 14.

74. NARA, "Report on Turkey," November 27, 1941, roll 26, M 1224, RG 59.

75. Hull, The Memoirs, 1369.

76. Plopeanu, "Difficult Road," 105-8.

77. NARA, "Training of Turkish Officers in Private Industry," September 18, 1944, No. 811.22767/9-1244, Box No. 3746, Decimal File 1940-1944, RG 59.

78. Örnek, "From Analysis to Policy," 946-7.

79. Persico, Roosevelt's Secret War, 234.

80. NARA, “Lanning MacFarland to William J. Donovan,” June 23, 1943, roll 79, M 1642, RG 226.

81. Cossaboom and Leiser, "Adana Station," 73.

82. Güvenç, “ABD Askeri Yardımı,” 261. 


\section{Notes on Contributor}

Ayşegül Avcı is Ph.D. candidate in the History Program at I.D. Bilkent University, Ankara/Turkey with a focus on the first American merchant family in İzmir, Ottoman Empire in the first half of the nineteenth century. Through the Offley Family, the diplomatic, cultural and commercial relations are discussed. She received her BA from the Department of American Culture and Literature in 2006 at Hacettepe University and her MA from the Department of History in 2006 at Bilkent University. Her MA Thesis, entitled "American Propaganda in Turkey and Economic, Military and Cultural Warfare against Germany during the Second World War" scrutinizes Turkish-American relations during World War II from the propaganda point of view.

\section{References}

Akmeşe, Handan Nezir. The Birth of Modern Turkey: The Ottoman Military and the March to World War I. London: I.B. Tauris, 2005.

Barutçu, Faik Ahmet. Vol. 1 of Siyasi Hatıralar. Ankara: 21. Yüzyıl Yayınları, 2001. Başbakanlık Cumhuriyet Arşivi (BCA), Ankara, Turkey.

Callender, Harold. "Turks, Spain and Italy Begin to See the Light." New York Times, February 14, 1943, E5.

Chandler, Alfred D., Jr. "The Competitive Performance of U.S. Industrial Enterprises since the Second World War.” The Business History Review 68, no. 1 (1994): 1-72.

Congressional Record-Senate, Library of Congress, Washington, DC.

Cossaboom, Robert, and Gary Leiser. "Adana Station 1943-45: Prelude to the Postwar American Military Presence in Turkey." Middle Eastern Studies 34, no. 1 (1998): 73-86.

Deringil, Selim. Turkish Foreign Policy During the Second World War: An 'Active' Neutrality. Cambridge: Cambridge University Press, 2004.

Doğaner, Yasemin. “İkinci Dünya Savaşı Yıllarında Türkiye'de Nazi Propagandası (Emniyet Genel Müdürlüğü Raporlarına Göre).” Hacettepe Üniversitesi Türkiyat Araştırmaları Dergisi 17 (2012): 65-81.

Erkilet, Emir H. Şark Cephesinde Gördüklerim. İstanbul: Hilmi Kitabevi, 1943.

Fox, Annette Baker. The Power of Small States: Diplomacy in the World War II. Chicago: University of Chicago Press, 1959.

Gerede, Hüsrev. İkinci Dünya Savaşı Sırasında Türkiye’nin Berlin Büyükelçisi Hüsrev Gerede'nin Anıları: Harb İçinde Almanya. İstanbul: ABC Ajansı Yayınları, 1994.

Glasneck, Johannes. Türkiye’de Faşist Alman Propagandası. Ankara: Onur Yayınları, 1976.

Gramer, Ailen G. “Turkey in Search of a Protector: 1918-1947.” Current History 13, no. 75 (1947): 280-7.

Güvenç, Serhat. "ABD Askeri Yardımı ve Türk Ordusunun Dönüşümü: 19421960.” In Türkiye'de Ordu, Devlet ve Güvenlik Siyaseti, edited by Evren Balta Paker and İsmet Akça, 255-84. İstanbul: İstanbul Bilgi Üniversitesi Yayınları, 2010.

Harris, George S. Troubled Alliance: Turkish-American Problems in Historical Perspective 1945-1971. Washington, DC: American Enterprise Institute for Public Policy Research, 1972.

Hull, Cordell. Vol. II of The Memoirs of Cordell Hull. London: Hodder \& Stoughton, 1948. 
Ísmet İnönü'nün TBMM'deki Konuşmaları: 1920-1973. Ankara: TBMM Kültür Sanat ve Yayın Kurulu, 1993.

Karabekir, Kazım. Ankara'da Savaş Rüzgarları. İstanbul: Emre Yayınları, 1995.

Koçak, Cemil. Türk-Alman İlişkileri 1923-1939. Ankara: Türk Tarih Kurumu Basımevi, 1991.

Leiser, Gary. “The Turkish Air Force, 1939-1945: The Rise of a Minor Power.” Middle Eastern Studies 26, no. 3 (1990): 383-95.

Millman, Brock. "Turkish Foreign and Strategic Policy 1934-42." Middle Eastern Studies 31 no. 3 (1995): 483-508.

National Archives and Records Administration (NARA), College Park, MD.

Örnek, Cangül. "From Analysis to Policy: Turkish Studies in the 1950s and the Diplomacy of Ideas.” Middle Eastern Studies no. 6 (2012): 941-59, doi:10.1080/ 00263206.2012 .723630 .

Örnek, Cangül, and Çağdaş Üngör. Turkey in the Cold War: Ideology and Culture. London: Palgrave Macmillan, 2013.

Özcan, Gencer. “Türkiye'de Cumhuriyet Dönemi Ordusunda Prusya Etkisi.” In Türkiye'de Ordu, Devlet ve Güvenlik Siyaseti, edited by Evren Balta Paker and İsmet Akça, 175-221. İstanbul: İstanbul Bilgi Üniversitesi Yayınları, 2010.

Özgüldür, Yavuz. Türk-Alman İlişkileri 1923-1945. Ankara: Genelkurmay Basımevi, 1993.

Persico, Joseph E. Roosevelt's Secret War, FDR and World War II Espionage. NewYork: Random House, 2001.

Plopeanu, Emanuel. "The Difficult Road to a Special Partnership: The Turkish-US Relations During World War Two." Valahian Journal of Historical Studies 17 (2012): 105-26.

Rooney, Chris B. "The International Significance of British Naval Missions to the Ottoman Empire, 1908-14.” Middle Eastern Studies 34 no. 1 (1998): 1-29.

Taylor, Henry J. "Nazi Plane Offer Made to Turks, but Proposal Has a String to It." New York Times, August 4, 1942, 4.

Thomas, Lewis V., and Richard N. Frye. United States and Turkey and Iran. Hamden, CT: Archon Books, 1971.

Toker, Metin. Türkiye Üzerinde 1945 Kabusu: 2. Dünya Savaşından Sonra TürkSovyet ve Türk-Amerikan İlişkileri Üzerine Bir İnceleme. Ankara: Akis, 1971.

Türk Silahlı Kuvvetleri Tarihi (1908-1920). Vol. 3. Ankara: Genelkurmay Basımevi, 1971.

Ülman, Haluk. Türk-Amerikan Diplomatik Münasebetleri 1939-1947. Ankara: Ankara Üniversitesi Siyasal Bilgiler Fakültesi Yayınları, 1961.

Vanderlippe, John M. “A Cautious Balance: The Question of Turkey in World War II." The Historian 64 no. 1 (2001): 63-80.

Vere-Hodge, Edward Reginald. Turkish Foreign Policy, 1918-1948. AmbillyAnnemasse: Impr. Franco-Suisse 1950.

Weber, Frank G. The Evasive Neutral, Germany, Britain and the Quest for a Turkish Alliance in the Second World War. Columbia: University of Missouri Press, 1979.

Weisband, Edward. Turkish Foreign Policy 1943-1945. Princeton, NJ: Princeton University Press, 1973.

Yalçın, Hüseyin Cahid. "Roosevelt ve Turkiye.” Yeni Sabah, October 7, 1942.

Yalman, Ahmed Emin. Turkey in My Time. Norman: University of Oklahoma Press, 1956.

Yalman, Ahmed Emin. Yakın Tarihte Gördüklerim ve Geçirdiklerim. İstanbul: Pera, 1997. 